\title{
REMARKS ON VERBO-TONAL PHONETICS FOR A COMMUNICATIVE CONTEXT
}

\author{
Xose Padilla García
}

Universitat d'Alacant

Resumen

El objetivo de este artículo es presentar algunas técnicas de corrección fonética a los profesores de lengua extranjera, especialmente a aquellos que trabajan en un contexto comunicativo (Arnold et al. 2005) y no están familiarizados con la clase de pronunciación. El artículo se divide en dos partes: en primer lugar, presentaremos las contribuciones más generales del Método verbo-tonal (Asp 2006; Berré (ed.), 2005; Billières, 2002, 2014; Calvo and Murillo, 2012; Dalmau et al., 1985; Guberina, 1956, 1961; Guberina and Murillo 2008; Murillo, 2002; Intravaia, 2002; Renard, 1971, 1979, 2010; Renard and van Vlasselaer 1976; Roberge, 2002; etc.); en segundo lugar, propondremos algunas técnicas para practicar la corrección fonética en español. Esta propuesta, sin embargo, puede aplicarse también a otras lenguas.

PALABRAS CLAVE: enfoque comunicativo, instrucción explícita de la pronunciación, fonética, español como segunda lengua, método verbo-tonal.
Abstract

The aim of this paper is to make phonetic correction techniques available to foreign language teachers, especially to those who work in a communicative context (Arnold et al. 2005) and are not familiar with pronunciation class. This paper is divided into two sections: firstly, we will introduce the verbo-tonal method's more general contributions (Asp 2006; Berré (ed.), 2005; Billières, 2002, 2014; Calvo and Murillo, 2012; Dalmau et al., 1985; Guberina, 1956, 1961; Guberina and Murillo 2008; Murillo, 2002; Intravaia, 2002; Renard, 1971, 1979, 2010; Renard and van Vlasselaer 1976; Roberge, 2002; etc.); secondly, we will propose some techniques to practice phonetic correction in Spanish. This proposal, however, can be applied to other languages as well.

KEY WORDS: communicative approach, explicit instruction of pronunciation, phonetics, Spanish as a second language, verbo-tonal method. 


\section{INTRODUCCIÓN ${ }^{1}$}

The aim of this paper is to make phonetic correction techniques available to foreign language teachers, especially for those who work in a communicative context (Arnold et al. 2005) and are not familiar with pronunciation class. This paper will make use of the verbotonal method (hereafter, VTM) as a starting point; however, our goal is not to describe exhaustively each of the verbo-tonal techniques, but to introduce general proposals that awaken the teachers' interest in the method, which can be implemented with new readings in the future. ${ }^{2}$. This work is divided into two sections: firstly, we will introduce the VTM's more general contributions (Asp 2006; Berré (ed.), 2005; Billières, 2002, 2014; Calvo and Murillo, 2012; Dalmau et al., 1985; Guberina, 1956, 1961; Guberina and Murillo 2008; Murillo, 2002; Intravaia, 2002; Renard, 1971, 1979, 2010; Renard and van Vlasselaer 1976; Roberge, 2002; etc.); secondly, we will propose some techniques to practice phonetic correction in Spanish. This proposal, however, can be applied to other languages as well.

\section{GeNERAL PROPOSALS OF THE VERBO-TONAL METHOD}

Between the 30s and 50s, Guberina (1956, 1961), a specialist in speech pathologies, developed a clinical treatment to help children with hearing impairment ${ }^{3}$. His research, carried out in collaboration with specialists from other disciplines (psychology, medicine, engineering, etc.), concluded that the best way to improve a patient's hearing capacity is to stimulate the brain. Only a part of the elements that constitute the acoustic signal are linguistically relevant, thus a limited number of frequencies allow for the identification and integration of the whole message. In this sense, Guberina argued that if it were possible to delimit and to isolate the really important elements of the acoustic signal (perceptive optimality), and to train the damaged ear in the identification of these elements, people with a hearing impairment would take an important step (Asp, 2006).

\subsection{Focus on perception}

In parallel to the clinical work, Guberina and his colleagues soon realized that some of the ideas and techniques of their clinical therapies could be successfully transferred to the field of foreign language teaching (Renard, 1979; Renard and van Valsselaer, 1976; Berré (ed.), 2005; etc.). A key element to understanding how the VTM took the leap from the clinics to the classrooms was the influence of Trubetzkoy's (1939) theories in this methodology. Trubetzkoy pointed out that the phonological system of a given language is like a sieves through which everything we hear passes. The distinctive features that contribute to the identification of a phoneme remain in it; the rest are either ignored, or used for pragmatic or expressive purposes. Trubetzkoy argued that this way of analysing what we hear which, after definitive acquisition of the mother tongue becomes automatic-is also used by students learning an L2. Whenever students are exposed to a foreign linguistic sound, they will interpret it using the phonological sieve acquired in their childhood.

\footnotetext{
${ }^{1}$ This work was supported by the Ministerio de Economía, Industria y Competitividad (MINECO, Spain) under the Grant EI habla con significado emocional y expresivo: análisis fono-pragmático y aplicaciones (FFI2017-88310-P/MINECO).

${ }^{2}$ See: http://www.intravaia-verbotonale.com; or http://liceu.uab.cat/stage_MVT/biblio.html.

${ }^{3}$ See: http://www.verbotonal.org/index.php.

${ }^{4}$ The VTM is included in the SGAV methodology (see, for example, Renard and van Vlasselaer; 1976; Berré (ed.), 2005; Guberina and Murillo, 2008; etc.).

5 "Each person acquires the system of his mother tongue. But when he hears another language spoken he instinctively uses the familiar phonological sieve of his mother tongue to analyse what has been said" (Trubetzkoy 1939, 52). 
According to Trubetzkoy's theory, students are deaf to certain foreign language sounds, those that do not exist in their mother tongue. Therefore, VTM proposes that real deafness as well as phonological deafness have characteristics and treatments in common. Taking these ideas as a starting point, Guberina (1961) establishes that perception is focal in pronunciation learning and logically it must precede production.

The relevance of perception under the VTM approach is extrapolated, on the other hand, to all learning processes of a foreign language. If the student has problems with phonic perception, this deficiency will also affect other aspects of learning, such as vocabulary, grammar or reading (Alazard et al. 2012). The less perceptive skill the student has, the fewer lexical domain and fewer intuitive grammatical reflection. Consequently, the entire learning process of the $\mathrm{L} 2$ is conditioned by pronunciation.

\subsection{Focus on suprasegmentals}

The VTM highlights the importance of the suprasegments and proposes that prosody (stress, rhythm and intonation) should precede the sounds in the sequence of teaching. Suprasegmentals are important for a great number of reasons (intonation modality, organizing the spoken discourse, expressive and emotional meaning, etc.), but especially because sounds are always produced within a rhythmic-intonation movement (Bellière, 2014). A top-down sequence of learning, i.e., to begin the lessons by practising suprasegmentals, is, therefore, according to the VTM, a more effective way to improve the pronunciation of the students.

The relevance of suprasegmentals, on the other hand, is easily embedded in research on children's language acquisition. According to scholars (Echols and Marti 2004; Vihman et al. 2004; Lintfert and Möbius 2013), babies' first contact with language is through its melody. Babies react to the melody that accompanies adults' words allowing them to make the first segmental partitions in the discourse. This means that prosodic development acts as one kind of filter to find out possible word-like sequences in the speech stream (Shukla et al. 2007). In agreement with this, foreign language students should follow a similar path.

Furthermore, this proposal, going from large to small pieces, supposed a radical turn from the traditional way to face the sequence of learning pronunciation, since, traditionally, the opposite order has been followed (articulatory method').

\subsection{Spoken and written language}

The VTM also claims that speaking and writing must remain separate in the first phases of learning (Renard and van Vlasselaer, 1976). Before they begin to write students need to have an important command of speech, and consequently of pronunciation (perception and production). Starting with the written language, or combining both system, provides a false security that paradoxically will negatively condition the pronunciation and, in general, the whole learning of an L2.

The VTM points out that using the writing system in the early stages of learning is a mistake. When students read, they do not listen, and doing so impairs their perceptive skill. It is

\footnotetext{
${ }^{6}$ Most of the instruction in pronunciation teaching has been labelled under the term articulatory method. This method bases the phonetic correction on the conscious control of the articulatory organs and uses mainly two types of activities: minimal pairs and repetition. For Spanish, see Cañal (2003), Fernández Díaz (1999), Fernández and de Santiago (1997), Nuño and Franco (2001), Masip (1999), Moreno Fernández (2000), Romero and González (2002), Sánchez and Matilla (1974), Siles (1994), etc. For English, see Brookes (1994), Hewins (2004), Gómez and Sánchez, 2016), etc. 
possible to get an idea of the verbo-tonal proposal if we reflect, for example, on the path followed by the viewer of a film with subtitles (Renard and van Vlasselaer 1976). At the beginning of the film, the viewer usually hears and reads at the same time, but as the film advances, reading usually becomes the only mechanism employed by the viewer. The written words block the auditory perception and the ear seems to close.

Although this verbo-tonal suggestion may involve overcoming some strongly imbedded ideas, the classroom experience of teachers and the process of acquisition of the mother tongue seems to reinforce the proposal. Taking the leap from the spoken language to the written language is relatively easy, but not vice versa.

\subsection{Non-verbal language}

The VTM highlights the importance of relating pronunciation to non-verbal language (Bellières, 2002). The movement of the hands and the body, the face gestures, the way of looking, etc. accompany the sounds when we talk. Using verbo-tonal terminology, macroception (or perception of general body movements) and microception (or perception of articulation) interact in oral communication (Guberina and Murillo 2008). Accordingly, teachers should teach pronunciation in a dynamic way: standing, sitting, back-talk, etc.

Although the VTM's idea can be applied to the learning of pronunciation in general terms, there are specific cases in which the multimodal character of pronunciation becomes especially obvious. For example, it is difficult to pronounce an order with a gesture that opposes the perlocutionary act of command, since intonation works in synchrony with para-verbal gestures (Billières, 2002, 2014; Balog and Brentari 2008; González-Fuente 2017). In fact, from the point of view of articulation, there is a close link between the general tension of the face and the tension of the vocal cords that covers the whole process of special phonic characteristics (Tatham and Morton 2011). Something similar happens with the practice of tones in tonal languages. The pronunciation of tones in Chinese, for instance, is so linked to the movements of the body that it is very difficult to put them ([ma]] (mother), [ma-1] (hemp), etc.) into practice if the foreign student is statically sitting (Tzu-Hiu 2006; Tsai 2011).

In short, following the VTM, gestures and sounds form a mixed code that can only be separated artificially.

\subsection{The extra-linguistic factors}

Finally, the VTM emphasises the importance of extra-linguistic factors, which can include mood, personality, age, context and learning expectations, among others. These factorsall of them together, or separately-influence the way in which the student is related to pronunciation (Renard and van Vlasselaer; 1976; Intravaia, 2005). For instance, a part of the students' rejecting ${ }^{7}$ to pronunciation lessons has been related to the psychological obstacle (mood, personality, expectations, etc.) involved in articulating sounds in another language. For many students, foreign sounds are a kind of new suit that they do not feel like wearing. These students, moreover, often associate good pronunciation with

\footnotetext{
${ }^{7}$ The idea of the rejection of explicit instruction begins with the natural approach (Krashen and Terrell, 1983; Krashen 1985), it is developed later in the task-based model (Ellis, 2003, 2005) and remains partly today in the current communicative teaching. See Selinger and Shohami (1989). 
nativeness ${ }^{8}$ (learning expectations), and such a demanding goal also contributes negatively to consider pronunciation an attractive and useful class.

The VTM enhances the figure of the teacher as a key element to overcome all these obstacles. As Intravaia (2005: 123) points out, teachers must create: "(..) un climat d'emphatie, lever les blocages psycologiques et culturels par le respect de l'autre, la reconnaissance et la valorisation des différences, désamorcer les inhibitions susceptibles de surgir dans le groupe-class, instaurer un climat de solidarité, de collaboration et de connivence (...)".

\section{PHONETIC CORRECTION TECHNIQUES IN THE CLASSROOM}

In addition to the general proposals mentioned so far, it is possible to introduce specific techniques to deal with the phonetic correction of pronunciation problems in the classroom. In order to explain them more clearly, we will divide our exposition into three sections: a) the playful-affective component, b) the suprasegmentals and c) the segments. As mentioned before, we will take as a starting point problems related to the pronunciation of Spanish as L2.

\subsection{The relevance of the playful-affective environment}

With regard to the playful-affective techniques, an L2 student should adopt, as far as possible, an attitude similar to that of the children learning their mother tongue. Children see language mainly as a game, therefore, learners and teachers should be willing to play. To achieve this goal, it is necessary to avoid phonetic intellectualization in the classroom. The pronunciation teacher must know phonetics but does not have to teach it directly to the students. Indeed, a common mistake in the foreign language class is to think that teaching pronunciation is to teach phonetics. As Llisterri (2003) points out, the pronunciation class is not a class of phonetic theory but a place of communicative motivation whose objective is to solve the problems related to the perception and production of speech. Using games (Badia 1992; Hancock 1995; Cortés 2003) is a good strategy to create a propitiatory environment, as well as to combat prejudice and to relax tension. Interestingly, for example, students can be asked to imitate a non-native speaker's language to put themselves in the other's shoes, or to explain to their classmates how the language they are learning sounds to them (sweet, ugly, funny, serious, etc.). Exercises like these ones, or similar, work on confidence and encourage motivation and relaxation. Starting the pronunciation class with a game is always a good start.

The pronunciation class, on the other hand, should not last too long. 20 or 30 minutes are enough to develop an activity (Padilla, 2015). Longer classes cease to be effective because tired students and tired teachers are not able to maintain good models for a long time.

\footnotetext{
${ }^{8}$ Derwing and Munro (2015, 3-11) name foreign accent as accentedness: "the extend of difference perceived by speakers of one linguistic variety when listening to speakers of others varieties"; and add two more concepts: intelligibility, "a measure of the extended listener has understood what a speaker said" and comprehensibility, "the amount of effort that must be put in to understand speech". 


\subsection{Suprasegmentals}

With regard to the perception of suprasegmentals, the first step could be teaching learners to distinguish the different chunks (units) in which the discourse is organized', i.e., the rhythm. Spanish and English students, for example, have problems with rhythm when they learn English or Spanish as a foreign language (Wong 1987). The rhythm in English is stresstimed, that is to say, "speakers try to keep an equal time between the stressed syllables" (Roach 1997: 36). As a result, unstressed syllables are reduced and relaxed so that the duration of the chunks is constant (feet or rhythmic groups). The rhythm in Spanish is mainly syllable-timed (Toledo 1998). Syllables' length usually keep the same length regardless of whether they are stressed or unstressed. Consequently, unstressed syllables do not relax (at least not systematically). Both Spanish and English speakers transfer (Flege and Davidian 1985; Lleó 1997; etc.) the uses of their mother tongue to the L2. One way to help English students of Spanish to notice the rhythmic units is, for example, to dispense with words and hum the utterance. With humming exercises, the teacher can show the student how the sounds are grouped around the stressed syllable and how the syllables are usually isochronous. Setting the pace by clapping or hitting a table with hands, reading poems and tongue-twisters aloud, syllabication (syllable-by-syllable pronunciation) or simply showing the pauses that are made in a reading through punctuation are also good exercises to practice rhythm in syllabled-timed languages. These techniques could be complemented by examples of spontaneous speech (loaded talks, films, TV series, etc.) that allow the students to have direct contact with real prosodic codes.

With regard to intonation, it is necessary to enhance the perception problems related with a deficient identification of the pitch movements. In Spanish, statements and yes/no questions can be distinguished just by changing the final inflection (falling or rising) ${ }^{10}$. In order to improve students' perception, it is possible to use computer tools such as Praat (http://www.fon.hum.uva.nl/praat/) to show the students a visual representation of speech (Padilla, 2015). With the Praat software, and supplementary material, the student, in addition to hearing, can compare his/her productions to native patterns (in his/her mother tongue and in the L2). The link between melody and the drawing that represents it can be as well a useful tool to appreciate characteristics of pitch movements that are not always easy to notice just with the ear.

\footnotetext{
${ }^{9}$ The most primary function of suprasegmentals is to organize the spoken discourse. Sounds are not a chain of independent units but hierarchical blocks (Cantero 2002). Inside these blocks, the vowels (especially the stressed ones) have the main perceptive function. Given that, it is possible to distinguish two levels: a) the (phonic) word and b) the phrase. In syllable-timed languages, like Spanish, at the level of the word, unstressed syllables are organized around a stressed syllable making metrical feet or rhythmic groups ([la'kasa]; the house). At the level of the sentence, rhythmic groups are organized around a tonal inflection, that is to say, the last stressed syllable of the utterance, making intonation groups ([/la'kasa 'ez 'ßierðe//]; the house is green). See also Euler (2014).

${ }^{10}$ With regards to the movement that adopts the final inflection, falling or rising, three types of contours are differentiated in Spanish: statement (or falling), (yes/no) question (or rising) and suspension (or level-tone). While the final inflection is the most informative and important part of the intonation group, the intonation contour is formed by two other parts: 1) the anacrusis, the syllables before the first stressed syllable of the utterance; and 2) the body, the space between the first stressed syllable and the final inflection. The final inflection is the most informative and important part of the intonation group, the intonation contour is formed by two other parts: 1) the anacrusis, the syllables before the higher or lower with respect to the final inflection; the slope (decline), on the other hand, may be more or less regular; etc. (Cantero et al. 2005). 


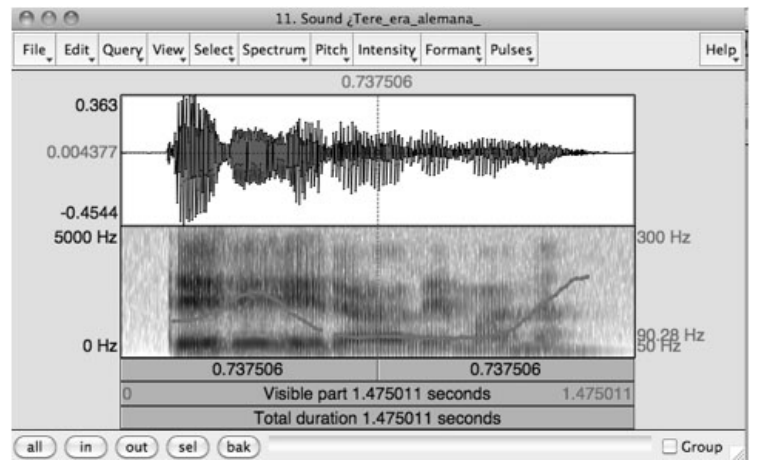

Figure 1. Yes/no question pattern in Spanish

If teachers are not familiar with the usage of this software, an alternative could be working with any exercise that aims to identify the parts and the form of the intonation contour; for example: draw the curve, place the arrow, identify the inflection, etc. (Cortés 2002, 2006, 2008; González Hermoso and Romero Dueñas, 2002; Lahoz 2007, 2012; Gil Fernández, 2007, 2012; Hidalgo and Cabedo 2012). The goal of these exercises -as it was with Praatis to reinforce the perception of intonation with visual elements.

\subsubsection{Productive training}

To practice the productive dimension of suprasegmentals, it is effective, for example, to use theatre plays and dialogues, in which the rhythm variations and the different contours of intonation (statement, question, suspension) are the objective.

Teachers can ask students to perform small plays, or dialogues, to practise these pronunciation difficulties while working at the same time motivating contexts (fun situations, personality of students, etc.). For example, it is possible to build multifunctional dialogues, in which expressive or pragmatic codes (sad/happy, with love/dislike, etc.) change (Roberge, 2002), despite using the same contours:

(1)

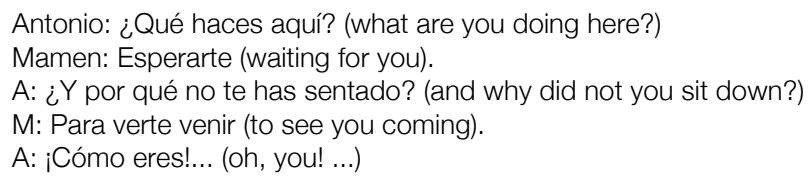

The utterances must be selected according to the students' needs, their level and the pronunciation problem to be practiced; and exercises must lead students not only to imitate native speakers but also to understand how all these prosodic constituents connect. These exercises not only can help to improve the student's pronunciation but will also turn the pronunciation class into a pleasant and creative place.

In addition, it is also possible to carry out an explicit phonetic correction of intonation through repetition. When practicing repetition it is useful, however, to use tools provided directly by speech. Thus, for example, if the objective is to practice the inflection of the melodic curve to differentiate intonation patterns, it is possible to segment specific utterances while maintaining the same contour (Poch 1999). The longer an utterance, the more difficult it is to intonate; therefore, it can be reduced to smaller pieces, keeping the same contour, and little by little start to add constituents to complicate the activity. A yes/no 
question in Spanish such as ¿Blanca y Joanna van de vacaciones a Londres? (Do Blanca and Joanna go to London on holidays?) can be reduced: ¿a Londres?, ¿de vacaciones a Londres?, etc., and, therefore, complexity will gradually increase.

\subsubsection{Image and writing}

As stated before, spelling difficulties the perception in the initial stages of learning, therefore, it would be better for students to be stimulated by photos or drawings, for example. Given that, it is possible, in many cases, to replace the writing with images when creating, for instance, an intonation exercise (Padilla 2015). Thus, an utterance in Spanish like A Mamen le gustan los perritos (Mamen likes puppies) can easily be transformed into:
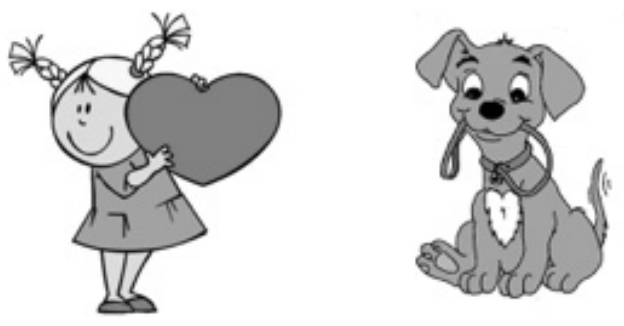

Figure 2. Mamen likes puppies.

With these exercises the students can make a connection between images (the girl and the puppy), meaning and intonation, but written words do not interfere the process.

\subsection{Segments}

The VTM also offers specific techniques to help foreign language learners in the process of perception and production of segments. For instance, it is necessary to analyse the articulatory characteristics of the sounds before preparing the possible correction techniques. One way to achieve this goal is to analyse their tension. The tenseness of the sounds can be classified then accordingly to two factors: 1) manner of articulation and 2) action of the vocal cords. Voiceless and close sounds are more tense than open and voiced sounds, therefore, it is possible to establish a scale (Renard, 1971, 1979, 2010) between all of them:

\begin{tabular}{|l|l|}
\hline+ tension & voiced plosive \\
& voiceless plosive \\
& voiced affricate \\
& voiceless affricate \\
& voiced fricative \\
& voiceless fricative \\
& nasal \\
& liquid (lateral, tap, trill) \\
& aproximants \\
& semivowels \\
& vowels \\
- tension & \\
&
\end{tabular}

Figure 3. Tension scale. 
Moreover, the tenseness of a segment is conditioned by its position within the major phonic units (syllable, rhythmic group and intonation group). In general, the onset of the group helps tension; and the end does the opposite (Guberina and Murillo, 2008). It is necessary to distinguish, on the other hand, whether the utterance is a statement or a question. Regarding to Spanish, in yes/no questions, unlike the statements, the rising final inflection is the tensest part of the intonation group.

Accordingly, the practice of a sound that is too tense in the scale should be set in the most helpful intonation context. For example, if a francophone student of Spanish pronounces the affricated consonant ch [t] ] as fricative [J] in a word like chabola (shanty), i.e., the learner pronounces the sound less tense than the standard Castilian-Spanish ${ }^{11}$ pronunciation, the first exercises they do should place the word chabola at the beginning of the utterance. For instance, the student should start by La chabola está en la montaña (the shanty is in the mountain) and not at the end El pastor vivía en una chabola (the shepherd lived in a shanty), where the articulatory tension decreases. On the contrary, if the tension target goes from more tense to less tense, it would do the opposite. The sequence of exercises must be organized according to the difficulty that the student may have in a given phonic context (tension and place in the utterance). First, the more favourable contexts, then the others.

The tension with which the sounds are pronounced is also affected by the learning context. An uncomfortable student, that is, stressed (with more tension), could condition unintentionally what he/she pronounces. Hence, the teacher should create a relaxed atmosphere so that the practice of pronunciation does not become a stressful or unpleasant experience (see section 2.5).

\subsubsection{Combinatory phonetics}

Another technique related to segment production is combinatory phonetics (or coarticulatory phenomena). This technique consists of analysing how to take advantage of the assimilative force of sounds in speech (assimilation, coarticulation, etc.) to achieve pronunciation goals (Renard and van Vlasselaer, 1976). Thus, when the teacher creates exercises, instead of performing an arbitrary selection of words, he/she could take into account the combination of adequate sounds to facilitate produce a specific sound.

For example, if Brazilian learners (Masip 1999; Arbulu 2000) of Spanish pronounce the alveolar [r] as the uvular [R], the goal of correction is to advance the articulation. Therefore, the training in this case should begin with words that combine the Spanish alveolar $[r]$ with front vowels [e, i], and not with back vowels [o, u]. It would be more useful, consequently, to start with words like reno (reindeer) and risa (laugh) than with others like romano (Roman) or ruso (Russian)'2.

An analogous problem, for instance, would be the longer pronunciation of the stressed vowels of Italian students learning Spanish: ['pi: so] with long [i:] for ['piso] with short [i] (Arroyo 2009). Since, in this case, the purpose of correction is to make the vowel shorter, it is possible to use the stop preceding the plosive consonants as a helpful combination for the correction. Thus, to begin the phonetic correction by ['pito] (whistle) vs. ['piso] (flag) is

\footnotetext{
${ }^{11}$ In Spanish of America, southern Spain and Canary Islands the fricative []] is the common pronunciation of ch (see for example, Hualde 2005).

${ }^{12}$ Likewise, it is also possible to help the pronunciation of the Spanish [r], by beginning the training with the combination of consonant $+[r]$ (Enrique, alrededor) rather than with others as the onset of the syllable (Ramón) or between vowels (perro), since the previous consonant to sound [r] serves as a support to its articulation. 
to favour automatically a shorter pronunciation of the stressed [i:] of Italian speakers (Poch, 1999). Not doing so, on the other hand, would hinder the learning process for free.

\subsubsection{Variation of pronunciation}

Another technique related to segments is the variation of pronunciation or phonic change. This technique tries to drive the student's attention to the opposite direction of the error by modifying the perception/production of the sound that creates some difficulty (Renard and van Vlasselaer, 1976; Poch, 1999).

Speakers of Arabic, for example, have difficulties to perceive the Spanish phonemes /e/ and $/ \mathrm{i} /$, and produce [i] for $/ \mathrm{e} / \mathrm{/} / \mathrm{i} /$. Articulatory method proposed using minimal pairs containing this phonological opposition: ['pela] (coin) ['pila] (pile), ['tela] (cloth) vs. ['tila] (lime); etc. The VTM, on the contrary, claims to drive the student's attention to the perception of the open/close scale of vowels. Accordingly, starting the training with oppositions such as ['pala] ['pila], which focus on the open/close scale, rather than with specific minimal pairs such as ['pela] ['pila], would be more useful.

A similar technique can be used to help produce specific sounds. One well-known example is the Chinese speakers' difficulty pronouncing [r] (Cortés 2007). As opposed to using repetition exercises such as: Ramón rema en el río (Ramón rows along the river), it seems more appropriate to analyse the error according to the characteristics of the place and manner of articulation of the sound. Spanish [r] has two characteristics: it is alveolar, that is, the tongue is placed behind the upper teeth (or alveolar ridge); and trill, the tip of the tongue is mobile enough to vibrate. Based on this description, students need to focus on two elements: a) front articulation and b) vibration as the product of a kind of succession of small plosives. In short, instead of beginning the practice by repeating the [r], it is possible to start with a plosive model such as [t], then add the voicing with [d], and only at the end pass to the trill sound [r] (Poch 1999).

These correction techniques were conceived as tools for phonetic accuracy. However, they can also be seen as phonetic training strategies that aim to facilitate the communicative capacity of students. As Celce-Murcia et al. (1996: 9) claimed, learners should be able "to surpass the threshold level so that their pronunciation will not detract from their ability to communicate".

\section{CONCLUSIONS}

Throughout these pages, we have briefly reviewed the use of the phonetic correction within the limits of the foreign language classroom by proposing techniques that may be useful to students and teachers. Many of the verbo-tonal proposals presented here are compatible with the communicative approach. For example, working only with images and sounds in class, avoiding the combination of the spoken language and the writing system (spelling) in the first lessons, starting to teach pronunciation with suprasegmentals, etc. can help the student both to manage the information that comes through the ear and to prepare them for an effective communication. We have also described more specific techniques, such as the tension scale, combinatory phonetics, or phonic change, which seek to teach pronunciation through explicit verbo-tonal phonetic methodology.

Obviously, teachers cannot be completely sure whether the practice of these explicit pronunciation proposals will raise the learners' pronunciation accuracy. Nevertheless, two 
reasons seem to particularly support this option. Firstly, students who are taught pronunciation seem to develop a greater confidence when they use the foreign language. Secondly, a high degree of accentedness cannot be compatible with an effectiveness and intelligibility in pronunciation. Avoiding a strong foreign accent and making oneself understood with phonic tools are part of the single process of learning a foreign language. Consequently, it makes sense to propose that phonetic techniques can collaborate with other forms of teaching so as to help students overcome the challenge of reaching a communicative pronunciation.

\section{REFERENCES}

AlazArd, C., C. Astésano and M. Billières (2012): «From Prosodic Skills to L2 Reading Proficiency: an Experimental Approach to L2 Phonetic Teaching Methods", in Busà, M. and A. Stella, eds., Methodological Perspectives on Second Language Prosody, Padova, CLEUP Sc., 55-59.

ARBulu, B. (2000): Estudio del sistema vocálico del español como lengua extranjera, Málaga, ASELE.

ARnold, J., Z. Dörnyel and C. Pugliese (2015): The Principled Communicative Approach: Seven criteria for Success, London, Helbling.

ARROYO, I. (2009): «Tensión y cantidad en la corrección fonética con telófonos: una propuesta para el aula de ELE», RESLA, 59-75.

AsP, C. (2006): Verbo-tonal Speech Treatment, San Diego, Plural Publishing.

BADIA, D. and M. VILA (1992): Juegos de expresión oral y escrita, Barcelona, Graó.

Balog, H. L. and D. Brentari (2008): «The relationship between early gestures and intonation", First Language, 28(2), 141-163.

BILLIĖRES, M. (2002): «Le corps en phonétique corrective», in R. Renard (ed.), Apprentissage d'une langue étrangère seconde, 2. La phonétique verbo-tonale, Bruxelles, De Boeck Université, 35-70.

BILLIĖRES, M. (2014): VADE-MECUM de phonétique corrective à l'usage des professeurs de fle, available in https://www.verbotonale-

phonetique.com/wp-

content/uploads/2014/11/vademecum.pptx.compressed.pdf.

BROOKES, M (1994): Pronounce English, Barcelona, Larouse.

Calvo, M.V. and J. Murillo, eds., (2012): Perception phonique et parole. Percepción fónica, habla y hablar, Mons, CIPA.

CANTERo, F. (2002): Teoría y análisis de la entonación, Barcelona, Edicions Universitat de Barcelona.

Cantero, F., R. Alfonso, M. Bartolí, A. Corrales and M. VIDAL (2005): «Rasgos melódicos de énfasis en español», Phonica, 1, 1- 40.

CAÑAL, V. (2003): «Enseñar pronunciación, entonación y melodía», Barcelona, International
House [available at]: http://www.encuentropractico.com/pdf03/canal.pdf. [Access: 22th Febr. 2016]

Celce-Murcia, M., D.M. Brinton and J. M. GoOdWIN (1996): Teaching Pronunciation, Cambridge, Cambridge University Press.

Celce-Murcia, M., Z. Dörnyel and S. Thurrell (1997): «Direct Approaches in L2 Instruction: A Turning Point in Communicative Language Teaching?», TESOL Quarterly, 31, 141-152.

Celce-Murcia, M., Z. Dörnyel, and S. Thurrell (1998): «On Directness in Communicative Language Teaching», TESOL Quarterly, 32, 116 -119.

CORTÉs, M. (2002): Didáctica de la prosodia del español: la acentuación y la entonación, Madrid, Edinumen.

CORTÉS, M. (2003): «Fonema, fonema... y bingo», Madrid, Instituto Cervantes, [available in]: http://cvc.cervantes.es/aula/didactired/. [Access: 5th Dec. 2016]

CORTÉS, M. (2006): «Dibujando la entonación», Madrid, Instituto Cervantes, [avaliable at]: http://cvc.cervantes.es/aula/didactired/. [Access: 5th Dec. 2016]

CORTÉs, M. (2007): «Enseñanza de la pronunciación a alumnos chinos», Madrid, Instituto Cervantes, [available at]: http://cvc.cervantes.es/aula/didactired/. [Access: 5th Dec. 2016]

Cortés, M. (2008): "Divide las palabras... y vencerás", Madrid, Instituto Cervantes, [available at]: http://cvc.cervantes.es/aula/didactired/. [Access: 5th Dec. 2016]

Dalmau, M., M. Miró and D. Molina (1985): Correcció fonètica (mètode verbo-tonal), Barcelona, Eumo.

DerWing, T. M. and M.J. MunRo (2005): «Second Language Accent and Pronunciation Teaching: A Research-Based Approach", TESOL Quarterly, 39(3), 379-397.

DeRWING, T. M. and M.J. MunRo (2015): Pronunciation Fundamentals, Amsterdam, John Benjamins Press.

Echols, C. H. and N. C. MARTI (2004): «The Identification of Words and Their Meanings: From Perceptual Biases to Language-Specific 
Cues», in Hall, D. G. and S. R. Waxman, eds., Weaving a Lexicon, Cambridge, MA, MIT Press, 41-78.

ELLIS, R. (2003): Task-Based Language Learning and Teaching, Oxford, Oxford University Press.

ELLIS, R. (2005): «Principles of Instructed Language Learning", Assian EFL Journal, 1, 1-16.

EULER, S. (2014): «Approaches to Pronunciation Teaching: History and Recent Developments", in Szpyra-Kozłowska, J., E. Guz, P. Steinbrich and R. Święciński, eds., Recent developments in applied phonetics (Studies in Linguistics and Methodology), Lublin, Wydawnictwo KUL, 3578.

FERnÁndeZ DíAZ, R. (1999): Prácticas de fonética para hablantes de portugués, Madrid, Arco/Libros.

FERNÁNDEZ GonZÁLEZ, J. and J. DE SANTIAGO (1997): Fonética básica del español para anglohablantes, Salamanca, Plaza Universitaria Ediciones.

FLEGE, J. and R. DAVIDIAN (1985): «Transfer and Speech Production», Applied Psycholinguistics, 5, 323-347.

GIL FERNÁNDEZ, J. (2007): Fonética para profesores de español: de la teoría a la práctica, Madrid, Arco-Libros.

GIL FeRnÁndeZ, J. (2012): Aproximación a la enseñanza de la pronunciación en el aula de español, Madrid, Edinumen.

GómeZ, M. Á. and T. SÁNCHEZ (2016): English Pronunciation for Speakers of Spanish, Boston/Berlin, De Gruyter/Mouton.

GonZÁlez-Fuente, S. (2017): Audiovisual Prosody and Verbal Irony, Barcelona, Publicaciones de la UPF.

González Hermoso, A. and C. Romero Dueñas (2002): Fonética, entonación y ortografía, Madrid, Edelsa.

GuberinA, P. (1956): «L'audiométrie verbo-tonale at son application", Journal Français d'O.R.L., 6, 23-42.

GuBERINA, P. (1961): «La méthode audio-visualle structuro-globale et ses implications dans l'enseignement de la phonétique", Studia Romanica et Anglica Zagrabiensia, 11, 12-40.

GuBERINA, P. (2008): Retrospección, Mons, CIPA (traducción y prólogo de Julio Murillo).

Hancock, M. (1995): Pronunciation Games, Cambridge, Cambridge University Press.

HanCIN-BHATT, B. (2008): "Second language phonology in optimality theory", Phonology and Second Language Acquisition, 6, 117-146.

Hewins, M. (2004): Pronunciation Practice Activities, Cambridge, Cambridge Uni. Press.

HidAlgo, A. and A. CABEDo (2012): La enseñanza de la entonación en el aula de E/LE, Madrid, Arco/Libros.

HualdE, J. I. (2005): The Sounds of Spanish, Cambridge, Cambridge University Press.

INTRAVAIA, P. (2005): "La formation verbo-tonale des professeurs de langues", in Berré M., ed.,
Linguistique de la parole et apprentissage des langues, Mons, CIPA.

INTRAVAIA, P. (2007): Formation des professeurs de langue en phonétique corrective. Le système verbo-tonal, Mons, CIPA.

IRUELA, A. (2004): Adquisición y enseñanza de la pronunciación en lenguas extranjeras, Barcelona, Universitat de Barcelona.

KRASHEN, S. D. (1985): The Input Hypothesis: Issues and implications, London, Longman.

KRAShen, S. D. and T. D. TeRrELL (1983): The natural approach, New York, Phoenix Elt.

LAHOZ, J. M. (2007): «La enseñanza de la entonación en el aula de ELE: cómo, cuándo y por qué", in Balmaseda, E., ed., Las destrezas orales en la enseñanza del español L2/L2, Logroño, ASELE, 705-19.

LAHOZ, J. M. (2012): «La enseñanza de la entonación, el ritmo y el tempo", in Gil Fernández, J., ed., Aproximación a la enseñanza de la pronunciación en el aula de español, Madrid, Edinumen, 93-132.

LINTFERT, B. and B. MöBIUS (2013): "Capturing Developmental Patterns in Intonation Acquisition: A Target-oriented Parametric Approach», BUCLD, 37, 1-12.

LLEÓ, C. (1997): La adquisición de la primera lengua y de las lenguas extranjeras, Madrid, Visor.

LLISTERRI, J. (2003): «La enseñanza de la pronunciación", Revista del Instituto Cervantes en Italia, 4, 1, 91-114.

Nuño, P. and J. R. Franco (2001): Ejercicios de fonética. Nivel Inicial, Madrid, Anaya.

MASIP, V. (1999): Gente que pronuncia bien 1. Curso de pronunciación española para brasileños, Barcelona, Difusión.

Moreno Fernández, F. (2000): Ejercicios de fonética para hablantes de inglés, Madrid, Arco/Libros.

MuRILLO, J. (2002): «Des réalisations phoniques dans l'enseignement / apprentissage des langues», in Renard, R., ed., Apprentissage d'une langue étrangère seconde, 2. La phonétique verbo-tonale, Bruxelles, De Boeck Université, 279-315.

PADILlA, X. A. (2015): La pronunciación del español. Fonética y enseñanza de lenguas, Alicante, Servicio de Publicaciones de la UA.

$\mathrm{Poch}$, D. (1999): Fonética para aprender español: pronunciación, Madrid, Edinumen.

RENARD, R. (1971): «Sur le recours a la tension en phonétique corrective», Revue de Phonétique Appliquée, 17, 71-87.

RENARD, R. (1979): Introduction à la méthode verbo-tonale de correction phonétique, Bruxelles-Mons, CIPA.

RENARD, R. (2010): «Sur le recours a la tension en phonétique corrective", Structuro-global et verbo-tonal. Variations 1962-2010. Essais de didactique des langues, Mons, CIPA, 171-180. 
RenARD, R. and J.J. van VLAsselaeR (1976): Foreign Language Teaching with an Integrated Methodology: the SGAV (Structuro-Global Audio-Visual) Methodology, Paris, Didier.

ROACH, P. (1997): Phonetics, Oxford, Oxford University Press.

RoBERGE, C. (2002): «Les intonations logique et affective, les grandes oubliées de l'éducation à la parole", in Renard R., ed., Apprentissage d'une langue étrangère seconde, 2. La phonétique verbo-tonale, Bruxelles, De Boeck Université, 131-154.

Romero, C. and A. González (2002): Tiempo para pronunciar. + de 100 ejercicios, Madrid, Edelsa.

SÁnCHEZ, A. and J. A. MATILla (1974): Manual práctico de corrección fonética del español, Madrid, SGEL.

Selinger, H. and E. ShOHAml (1989): Second Language Research Methods, Oxford, University Press.

SILES, J. (1994): Ejercicios de pronunciación de español, Madrid, SGEL.
SHUKLA, M., M. NESPOR and J. MEHLER (2007): «An Interaction between Prosody and Statistics in the Segmentation of Fluent Speech», Cognitive Psychology, 54 (1), 1-32.

TATHAM, M. and K. MORTON (2011): A Guide to Speech Production and Perception. Edinburgh, Edinburgh, Edinburgh University Press.

Toledo, G.A. (1998): El ritmo en español, Madrid, Gredos.

TrubetZKoy, N.S. (1939): Principios de fonología, Madrid, Cincel.

TSAl, R. (2011): «Teaching and Learning the Tones of Mandarin Chinese», Scottish Languages Review, 24, 43-50.

TZU-HIU, K. (2006): Teaching Chine Tones and Intonation to Adult Advanced Learners, Oregon, University of Oregon.

Vihman, M. M., N. Satsuki, R. DePaolis and P. HALled (2004): «The Role of Accentual Pattern in Early Lexical Representation", Journal of Memory and Language, 50, 336-353.

WONG, R. (1987): Teaching pronunciation focus on English Rhythm and Intonation, New Jersey, Prentice-Hall Inc. 